\title{
DZIEDZICTWO TEOLOGICZNE W ELEKTRONICZNYCH BAZACH BIBLIOGRAFICZNYCH FEDERACJI BIBLIOTEK KOŚCIELNYCH „FIDES”. PRZEGLĄD INICJATYW
}

\begin{abstract}
Streszczenie
Przeanalizowano strony internetowe 80 bibliotek należących do Federacji Bibliotek Kościelnych „Fides” w poszukiwaniu informacji o podjętych w nich projektach bibliograficznych. Przedstawiono na przykładach zdobywane przez lata doświadczenie instytucji w zakresie budowy narzędzi informacyjnych i ochrony dziedzictwa teologicznego. Scharakteryzowano wytypowane bibliograficzne bazy danych, w podziale na bibliografie dziedzin i zagadnień, bibliografie wydawnictw ciągłych i zawartości czasopism oraz bibliografie osobowe i zespołów osobowych. Skonstatowano, że najważniejszym produktem bibliograficznym bibliotek zrzeszonych w „Fides” jest Elektroniczna Bibliografia Nauk Kościelnych, współtworzona z Biblioteką Narodową w Warszawie. Zbadane książnice najczęściej opracowywały natomiast bibliografie zawartości czasopism, które częściowo zostały wchłonięte przez bibliografię dziedzinową, a rzadziej inne bibliografie dziedzin i zagadnień oraz zespołów osobowych.

Słowa kluczowe: bibliograficzna baza danych; bibliografia; biblioteka kościelna; dziedzictwo teologiczne; Federacja Bibliotek Kościelnych „Fides”
\end{abstract}

\section{Rozważania wstępne}

Jednymi z prężniej rozwijających się grup bibliotek należących do Kościoła katolickiego w Polsce ${ }^{1}$ są te, które zrzesza Federacja Bibliotek Kościelnych

\footnotetext{
* Agnieszka Gołda - dr hab. bibliologii i informatologii, prof. UŚ; Instytut Nauk o Kulturze, Uniwersytet Śląski w Katowicach; e-mail: agnieszka.golda@us.edu.pl

https://orcid.org/0000-0001-6571-5304

${ }^{1}$ Ja.P. [J. Puchalski], Biblioteki kościelne, w: Encyklopedia książki, t. 1, Eseje - A-J, red. A. Żbikowska-Migoń, M. Skalska-Zlat, Wrocław 2017, s. 312. Por. też J. Walkusz, Zbiory i biblioteki kościelne w Polsce. Wprowadzenie w problematykę, „Kościół w Polsce. Dzieje i Kultura”, 4 (2005) s. 27-36.
} 
„Fides”. Organizacja została utworzona 23 września 1991 roku (osobowość prawną uzyskała w 1995 roku), by dążyć do unowocześnienia działalności bibliotek, przede wszystkim w zakresie automatyzacji ich katalogów. Stało się to dzięki programowi MAK, przygotowanemu w Bibliotece Narodowej w Warszawie.

Od początku celem aktywności bibliotek federacyjnych było usprawnienie narzędzi informacyjnych, dlatego już w 1993 roku podjęto prace nad katalogiem centralnym ich zasobów. „Fides” był też odpowiedzialny za inicjowanie baz bibliograficznych, czego wyrazem było powołanie Komisji do spraw Bibliografii. Wkrótce zaczęła powstawać Bibliografia Nauk Kościelnych, która stanowiła połączenie trzynastu różnych źródeł opracowywanych przez biblioteki związku².

Ten właśnie fragment ich działalności stał się przedmiotem omówienia. Jego celem było uzyskanie odpowiedzi na pytanie dotyczące realnego zaangażowania poszczególnych bibliotek w proces przygotowania źródeł bibliograficznych. Interesujące wydaje się również wskazanie typów powstających bibliografii oraz ich wstępna charakterystyka. Celem tekstu nie była natomiast analiza funkcjonowania książnic należących do Federacji. W części wprowadzającej zostały jednak zaprezentowane na przykładach wybrane elementy ich organizacji oraz narzędzia informacyjne, by ocenić wkład instytucji w proces uprzystępniania metainformacji o posiadanych materiałach.

By osiągnąc zakładane cele, między wrześniem a listopadem 2019 roku przeprowadzono analizę zawartości stron internetowych 80 bibliotek Federacji ${ }^{3}$. Wśród nich 31,25\% to biblioteki seminariów diecezjalnych, 20\% - zakonów męskich, 16,25\% - zakonnych seminariów duchownych, 7,50\% - wyższych szkół katolickich, po $6,25 \%$ - wydziałów teologicznych uczelni publicznych oraz diecezji, po $3,75 \%$ - parafii oraz instytutów teologicznych, a po $2,50 \%$ - specjalistyczne oraz zakonów żeńskich ${ }^{4}$. Oznacza to, że ok. 2/3 analizowanych instytucji to takie, które pełnią funkcje dydaktyczno-naukowe, co oczywiście przekłada się na sposób ich organizacji i oferowane użytkownikom usługi biblioteczno-informacyjne. Biblioteki te dysponują księgozbiorami pozwalającymi przede wszystkim pracownikom naukowym, klerykom i studentom na korzystanie z publikacji z zakresu filozofii, etyki, teologii moralnej, pastoralnej, fundamentalnej, dogma-

2 J. Witczak, Federacja Bibliotek Kościelnych FIDES po dwudziestu latach, „Bibliotekarz”, (2013) nr 7-8, s. 12-13; A. Muc, Elektroniczna Bibliografia Nauk Teologicznych jako źródto do badań historyczno-teologicznych, „Archiwa, Biblioteki i Muzea Kościelne”, 109 (2018) s. 301.

${ }^{3}$ Niektóre z bibliotek nie posiadają swoich stron WWW (Biblioteka Opactwa Benedyktynów w Tyńcu, Biblioteka Prowincji Ojców Bernardynów w Krakowie, Biblioteka Rzymsko-Katolickiej Parafii im. Najświętszej Maryi Panny i św. Bartłomieja Apostoła w Piekarach Śląskich, Biblioteka Wyższego Seminarium Duchownego Zgromadzenia Ducha Świętego w Bydgoszczy, Biblioteka Wyższego Seminarium Duchownego Zgromadzenia Księży Marianów w Lublinie) lub informacje na nich są znikome (Biblioteka Archidiecezjalnego Seminarium Misyjnego „Redemptoris Mater” w Warszawie, Biblioteka Klasztoru Ojców Karmelitów Bosych w Lublinie, Biblioteka Wyższego Seminarium Duchownego w Gościkowie-Paradyżu, Biblioteka Wyższego Seminarium Duchownego w Płocku).

${ }^{4}$ Wykaz bibliotek członkowskich, w podziale na typy instytucji: Baza: FIDES - ADRESY BIBLIOTEK, http://www.fides.org.pl/cgi-bin/makwww/makwww.exe?BM=03\&IZ=Typ\%F3w-inst. (dostęp: 20.09.2019). 
tycznej i teologii duchowości, ale też z psychologii, pedagogiki, religioznawstwa, historii, politologii, prawa oraz innych nauk społecznych i humanistycznych. Także i w pozostałych typach bibliotek można odnaleźć takie zbiory, które wspomagają formację duchową czytelników, ale nie brak zasobów o charakterze kompensacyjnym, oświatowym, artystycznym i rozrywkowym.

Wśród analizowanych bibliotek są takie, które mają długą historię, jak i powstałe całkiem niedawno. Trudne do odtworzenia bywają średniowieczne dzieje bibliotek zakonnych ${ }^{5}$. Poza nimi do najstarszych należą biblioteki diecezjalnych i archidiecezjalnych seminariów duchownych oraz niektóre biblioteki uczelni wyższych ${ }^{6}$. Zdecydowanie później powołano biblioteki specjalistyczne, diecezjalne, które powstawały na potrzeby duchowieństwa, na bazie książnic parafialnych, kapitulnych lub prywatnych kolekcji kapłanów, ponadto - reprezentujące wydziały teologiczne, instytuty teologiczne ${ }^{7}$ i parafie $^{8}$.

Historia bibliotek, ale i przypisane im współcześnie zadania, wpłynęły bezpośrednio na przechowywane zbiory. Wśród charakteryzowanych instytucji znajdują się wyjątkowe, jak Biblioteka Opactwa Benedyktynów w Tyńcu czy Archiwum i Biblioteka OO. Karmelitów Bosych na Piasku - najstarsza biblioteka karmelitańska w Polsce ${ }^{10}$. Stare zbiory, obejmujące rękopisy, inkunabuły i druki,

${ }^{5}$ W. Kęder, Biblioteka opactwa cystersów w Mogile - Krakowie w XVII wieku, ,Rocznik Bibliologiczno-Prasoznawczy”, 4/15 (2012) z. 1, s. 18.

${ }^{6}$ M.M. Grzybowski, Biblioteka Seminarium Duchownego od 1710 do 1990 roku, w: Biblioteka Wyższego Seminarium Duchownego w Płocku, red. W. Graczyk, Płock 2003, s. 73; W. Graczyk, Biblioteka płockiego Seminarium - przeszłość i teraźniejszość, „Niedziela”, edycja płocka, (2003) nr 50, https://www.niedziela.pl/artykul/22785/nd/Biblioteka-plockiego-Seminarium (dostęp: 4.11.2019); M. Olszewski, Biblioteka AWSD w Białymstoku, w: Archidiecezjalne Wyższe Seminarium Duchowne w Białymstoku 1945-1995. Księga jubileuszowa, red. S. Hołodok, Białystok 1995, s. 118; M. Olszewski, Biblioteka Archidiecezjalnego Wyższego Seminarium Duchownego w Biatymstoku, „Fides. Biuletyn Bibliotek Kościelnych”, (2005) nr 1/2 (20-21), s. 75; E. Ślemp, Biblioteka Wyższego Seminarium Duchownego w Przemyślu, „Fides. Biuletyn Bibliotek Kościelnych”, (2005) nr 1/2 (20-21), s. 88; A. Kaleta, Powstanie i rozwój Biblioteki Wyższego Seminarium Duchownego w Kielcach, „Kielecki Przegląd Diecezjalny”, 74 (1998) z. 4, s. 335; T. Garwoliński, Dzieje Biblioteki „Hosianum” (Braniewo - Olsztyn: 1565-2008), „Fides. Biuletyn Bibliotek Kościelnych”, (2008) nr 1-2 (26-27), s. 59-72.

${ }^{7}$ I. Krysiak, Biblioteka Instytutu Maryjno-Kolbiańskiego „,Kolbianum” w Niepokalanowie, „Fides. Biuletyn Bibliotek Kościelnych”, 21 (2015) nr 2 (41), s. 61-72.

${ }^{8}$ J. Witkowska, Jubileusz trzydziestolecia Biblioteki Parafialnej w Trzciance, „Fides. Biuletyn Bibliotek Kościelnych”, (2014) nr 1 (38), s. 243-244.

${ }^{9}$ G. Klimecka, Tynieckie rękopisy iluminiowane w zbiorach Biblioteki Narodowej przykładem benedyktyńskiej kultury piśmienniczej w XIV-XV w., w: Klasztor w kulturze średniowiecznej Polski. Materialy z ogólnopolskiej konferencji naukowej zorganizowanej w Dąbrowie Niemodlińskiej w dniach 4-6 XI 1993 przez Instytut Historii WSP w Opolu i Instytut Historyczny Uniwersytetu Wrocławskiego, red. A. Pobóg-Lenartowicz i M. Derwich, Opole 1995, s. 289-297; J.M. Marszalska, Biblioteka opactwa benedyktynów w Tyńcu w świetle jej inwentarzy, „Roczniki Biblioteczne”, 41 (1997) z. 1/2, s. 29-42.

${ }^{10}$ S. Sułecki, Księgozbiór klasztoru karmelitów na Piasku w Krakowie, Kraków 2014, s. 70-76, 79-116, https://www.academia.edu/8990832/Ksi\%C4\%99gozbi\%C3\%B3r_klasztoru_karme- 
są też swoiste dla innych bibliotek zakonnych ${ }^{11}$. Materiały o charakterze nauko-

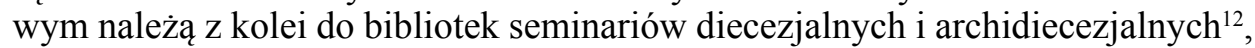
a największe liczebnie do bibliotek akademickich ${ }^{13}$. Mają one najczęściej charakter interdyscyplinarny (to zależy od różnorodności kierunków studiów) ${ }^{14}$. Zbiory teologiczne i filozoficzne, a także klasyka literatury i regionalia stanowią natomiast fundamenty bibliotek wydziałów teologicznych ${ }^{15}$.

\section{Narzędzia informacyjne}

Zgromadzone zasoby oraz pełnione przez biblioteki „Fides” zadania informacyjne, dokumentacyjne i edukacyjne stały się przedmiotem wielu działań biblioteczno-informacyjnych. $\mathrm{W}$ ich wyniku powstały narzędzia ${ }^{16}$, w tym powszechnie

lit\%C3\%B3w_na_Piasku_w_Krakowie (dostęp: 20.09.2019); Archiwum i Biblioteka OO. Karmelitów Bosych na Piasku, https://www.facebook.com/Karmelici.na.Piasku/ (dostęp: 20.09.2019).

${ }^{11}$ W. Umiński, Zabytkowe oprawy w Bibliotece Zgromadzenia Księży Misjonarzy w Krakowie w świetle wystaw, „Fides. Biuletyn Bibliotek Kościelnych”, 21 (2015) nr 2 (41), s. 3-18; G. Filipiuk, Archiwum i Biblioteka Warszawskiej Prowincji Kapucynów w Zakroczymiu, „Fides. Biuletyn Bibliotek Kościelnych", (2007) nr 1-2 (24-25), s. 113; M. Babicz, Stare druki Biblioteki Wyższego Seminarium Duchownego Towarzystwa Salezjańskiego w Ladzie nad Warta, „Archiwa, Biblioteki i Muzea Kościelne”, 80 (2003) s. 17-20.

${ }^{12}$ K. Rulka, Inkunabuly w Bibliotece Seminarium Duchownego we Włocławku, „Fides. Biuletyn Bibliotek Kościelnych”, (1996) nr 1/2, s. 58-65; R. Banach, Biblioteka Wyższego Seminarium Duchownego w Tarnowie z perspektywy historycznej, „Fides. Biuletyn Bibliotek Kościelnych”, 21 (2015) nr 1 (40), s. 46; T. Ceynowa, Wstępny katalog starych druków Biblioteki Wyższego Seminarium Duchownego w Koszalinie, „Bibliotekarz Zachodniopomorski”, 55 (2014) nr 4, s. 5-19; M. Florianowicz, Zbiór starych druków w Bibliotece Wyższego Seminarium Duchownego w Koszalinie, „Fides. Biuletyn Bibliotek Kościelnych”, 21 (2015) nr 1 (40), s. 81-102; A. Chlewicka, Biblioteka Wyższego Seminarium Duchownego Zgromadzenia Ducha Świętego w Bydgoszczy, https://repozytorium.ukw.edu.pl/bitstream/handle/item/5677/Biblioteka $\% 20 \mathrm{Wy} \%$ c5\%bcszego $\% 20$ Seminarium\%20Duchownego\%20Zgromadzenia\%20Ducha\%20\%c5\%9awi\%c4\%99tego\%20 w\%20Bydgoszczy.pdf?sequence=1\&isAllowed=y (dostęp: 04.11.2019); M. Przybysz-Stawska, Biblioteka Wyższego Seminarium Duchownego w Łodzi: wybrane zagadnienia, „Przegląd Biblioteczny", 81 (2013) z. 4, s. 489.

${ }^{13}$ Por. omówienie ankiety dotyczącej m.in. wielkości księgozbiorów bibliotek zrzeszonych w Federacji: J. Szulc, Biblioteki Federacji Bibliotek Kościelnych FIDES: omówienie wyników ankiety przeprowadzonej w 2007 roku, „Fides. Biuletyn Bibliotek Kościelnych”, (2007) nr 1-2 (24-25), s. 6-7.

${ }^{14}$ B. Zezula, Biblioteka Uniwersytecka Katolickiego Uniwersytetu Lubelskiego Jana Pawła II wczoraj i dziś, „,Fides. Biuletyn Bibliotek Kościelnych”, 22 (2016) nr 1 (42), s. 6-7; J. Bednarczyk, Biblioteka Papieskiej Akademii Teologicznej w Krakowie. Zarys działalności, „Analecta Cracoviensia. Studia philosophico-theologica edita a professoribus Cracoviae", $30 / 31$ (1998/1999) s. 427; A. Nowicka, Zarys dziejów Biblioteki Papieskiej Akademii Teologicznej w Krakowie, „Fides. Biuletyn Bibliotek Kościelnych”, (2005) nr 1/2 (20-21), s. 37, 40, 42.

${ }^{15}$ U. Grabińska, Powstanie i rozwój Biblioteki Wydziatu Teologicznego Uniwersytetu Opolskiego, „Fides. Biuletyn Bibliotek Kościelnych”, (2012) nr 2 (35), s. 41.

${ }^{16}$ Por. analizę różnego rodzaju narzędzi: A. Seweryn, Contemporary forms of communication with library users - the experiences of theological libraries in Poland, https://theo.kuleuven.be/ apps/press/beth/files/2019/09/BETH_Seweryn_mini.pdf (dostęp: 18.11.2019). 
używane katalogi biblioteczne. W charakteryzowanych bibliotekach przykłada się wagę do tego, by - jeśli nie są częścią katalogu centralnego Federacji - posiadać katalogi lokalne. „Fides” prowadzi „,centralny serwis informacji katalogowej i bibliograficznej", dając możliwość umieszczenia w jednym miejscu opisów wydawnictw zwartych, ciągłych, niesamoistnych wydawniczo części wydawnictw ciągłych oraz prac dyplomowych ${ }^{17}$. W 2010 roku podjęto decyzję o wyborze systemu Koha, w którym katalog współtworzy 21 bibliotek.

Opracowanie lokalnych katalogów elektronicznych rozpoczęło się w połowie lat 90. XX wieku ${ }^{18}$. Do wyjątków należą Biblioteka Główna Uniwersytetu Papieskiego Jana Pawła II w Krakowie, w której procesy informatyczne zainicjowano w 1989 roku $^{19}$ oraz Biblioteka Papieskiego Wydziału Teologicznego i Metropolitalnego Wyższego Seminarium Duchownego we Wrocławiu, w której komputeryzację wdrożono w latach 1991-1992. Z kolei w Bibliotece Diecezjalnej im. ks. Stanisława Kujota w Toruniu na przełomie 1999 i 2000 roku przedsięwzięto prace $\mathrm{w}$ programie MAK, by po kilku latach zdecydować o zmianie na system HORIZON, a od stycznia 2011 roku opisy dokumentów są widoczne w katalogu Biblioteki Uniwersytetu Mikołaja Kopernika w Toruniu. Tym samym, ,dzięki nawiązaniu współpracy z UMK wyprzedziła w tym względzie większość bibliotek kościelnych"20.

Obecnie w Federacji zrzeszone są biblioteki wykorzystujące kilka rodzajów programów i systemów katalogowych ${ }^{21}$ : MAK bez podłączenia do sieci oraz w sieci (także na stronie internetowej „Fides”), PATRON, HORIZON, PROLIB, Koha, VTLS-Virtua, ALEPH, SOWA, Symphony oraz własny program.

$\mathrm{W}$ analizowanych instytucjach najczęściej powstają katalogi zbiorcze (obejmujące opisy różnych typów dokumentów), ale prowadzi się też odrębnie katalogi czasopism, starych druków, rękopisów, dysertacji, kartografii, ikonografii, przezroczy, multimediów, ksiąg jubileuszowych, dokumentów beatyfikacyjnych i kanonizacyjnych.

${ }^{17}$ J. Witczak, Funkcjonowanie centralnego serwisu informacji katalogowej i bibliograficznej FIDES w 2011 roku, „Fides. Biuletyn Bibliotek Kościelnych”, (2012) nr 1 (34), s. 175-176.

${ }^{18}$ Przykładowo w Bibliotece Wyższego Seminarium Duchownego w Przemyślu i Bibliotece Wyższego Seminarium Duchownego Diecezji Koszalińsko-Kołobrzeskiej komputeryzację zaczęto w 1994 roku; w Bibliotece Wydziału Teologicznego Uniwersytetu Opolskiego (od 2006 roku ALEPH), Bibliotece Metropolitalnego Seminarium Duchownego w Lublinie - w 1997 roku; a w Bibliotece Wyższego Seminarium Duchownego w Płocku w 1998 roku. W świetle ankiety przeprowadzonej na przełomie 2006 i 2007 roku 93,6\% bibliotek zrzeszonych w „Fides” używało oprogramowania MAK. Szulc, Biblioteki Federacji Bibliotek Kościelnych, s. 7-8.

${ }^{19}$ Nowicka, Zarys dziejów Biblioteki Papieskiej, s. 47.

${ }^{20}$ B. Dygdała, Komputeryzacja Biblioteki Diecezjalnej w Toruniu: od MAK do NUKAT, „Fides. Biuletyn Bibliotek Kościelnych”, 22 (2016) nr 2 (43), s. 27.

${ }^{21} \mathrm{O}$ katalogach elektronicznych kilku bibliotek brak informacji (Biblioteka Archidiecezjalnego Seminarium Misyjnego „Redemptoris Mater” w Warszawie, Biblioteka Prowincji Ojców Bernardynów w Krakowie, Biblioteka Rzymsko-Katolickiej Parafii im. Najświętszej Maryi Panny i św. Bartłomieja Apostoła w Piekarach Śląskich, Biblioteka Teologiczna w Gliwicach, Biblioteka Wyższego Seminarium Duchownego w Płocku). 
Innym narzędziem informacyjnym powstającym w bibliotekach są wykazy nabytków. Funkcjonują one $\mathrm{w}$ zaledwie kilku bibliotekach ${ }^{22}$. Podjęto również starania o tworzenie lub współtworzenie bibliotek cyfrowych oraz repozytoriów instytucjonalnych ${ }^{23}$. Biblioteki udostępniają ponadto swoje zasoby $\mathrm{w}$ ramach Księgozbioru Wirtualnego Federacji FIDES. Ta różnorodność źródeł informacji, zwłaszcza w bibliotekach szkół wyższych oraz wydziałów teologicznych, spowodowała, że w ostatnich latach, by ułatwić użytkownikom korzystanie $\mathrm{z}$ nich, zdecydowano o zakupie multiwyszukiware ${ }^{24}$.

Należy zatem podkreślić, że biblioteki należące do Federacji mają duże (w przypadku bibliotek szkół wyższych, wydziałów teologicznych i wybranych placówek innych typów) lub przynajmniej podstawowe doświadczenie związane $\mathrm{z}$ organizowaniem dostępu do informacji o przechowywanych przez siebie zasobach.

\section{Opracowania bibliograficzne}

Jak wskazano w poprzedniej części tekstu, biblioteki Federacji przygotowują różne typy źródeł informacji, podając do wiadomości dane na temat zawartości księgozbioru lub jego części. Przez lata bibliotekarze zdobyli odpowiednie kompetencje, by tworzyć rejestry o charakterze ogólniejszym, niezwiązanym z lokalnym przechowywaniem zbiorów. Zanim jednak w analizowanych bibliotekach powstały elektroniczne bazy bibliograficzne, opracowywano bibliografie w postaci tradycyjnej ${ }^{25}$. Przykładowo w Instytucie Tomistycznym w Warszawie w od-

${ }^{22}$ Wykazy w bardzo różnej postaci funkcjonują m.in. w: Bibliotece Głównej Uniwersytetu Kardynała Stefana Wyszyńskiego w Warszawie, Bibliotece Uniwersyteckiej Katolickiego Uniwersytetu Lubelskiego Jana Pawła II, Bibliotece i Archiwum Diecezji Bielsko-Żywieckiej w Bielsku-Białej, Bibliotece Instytutu Filozoficzno-Teologicznego im. Edyty Stein w Zielonej Górze, Bibliotece Prymasowskiego Instytutu Kultury Chrześcijańskiej im. Stefana Kard. Wyszyńskiego w Bydgoszczy.

${ }^{23}$ Są to m.in.: Biblioteka Archidiecezjalnego Wyższego Seminarium Duchownego w Białymstoku, Biblioteka im. Jana Pawła II Wyższego Seminarium Duchownego w Legnicy, Biblioteka Diecezjalna w Sandomierzu, Biblioteka Prowincjalna przy Wyższym Seminarium Duchownym Franciszkanów OFMConv w Krakowie, Biblioteka Główna Uniwersytetu Kardynała Stefana Wyszyńskiego w Warszawie, Biblioteka Papieskiego Wydziału Teologicznego i Metropolitalnego Wyższego Seminarium Duchownego we Wrocławiu, Biblioteka Wyższego Seminarium Duchownego w Tarnowie.

${ }^{24}$ Multiwyszukiwarka Primo znalazła zastosowanie w Bibliotece Uniwersyteckiej Katolickiego Uniwersytetu Lubelskiego Jana Pawła II, a EBSCO Discovery Service (EDS) w Bibliotece Głównej Uniwersytetu Kardynała Stefana Wyszyńskiego w Warszawie, Bibliotece Głównej Uniwersytetu Papieskiego Jana Pawła II w Krakowie oraz Bibliotece Wydziału Teologicznego Uniwersytetu Mikołaja Kopernika w Toruniu.

${ }^{25}$ Znacznie częściej opracowywano katalogi. Dla przykładu można wymienić prace z ostatnich lat: Bibliografia druków zwartych II obiegu w zbiorach Biblioteki Archidiecezjalnego Wyższego Seminarium Duchownego w Białymstoku (Białystok 2005) Mieczysława Olszewskiego, Katalog inkunabułów Biblioteki Wyższego Seminarium Duchownego Metropolii Warmińskiej „Hosianum” w Olsztynie (Olsztyn 2007) opracowany przez Jana Obłąka, Zoję Jaroszewicz-Pieresławcew i Juliana Wojtkowskiego, Tradycja tomistyczna w zbiorach Biblioteki Studium OO. Dominikanów : katalog druków: XV-XVIII w. (Warszawa 2008) Moniki Mydel i Żanety Kubic, Inwentarz rękopisów 
stępie 10-letnim ogłoszono katalogi czasopism teologicznych z 68 bibliotek, pt. Wykaz czasopism teologicznych i filozoficznych w bibliotekach polskich (pierwsza edycja w 1958, a wyd. 2 popr. i uzup., Warszawa 1968). Wydano także publikację-Polskie czasopisma religijno-spoleczne $w$ XIX wieku : materiaty do katalogu pod redakcją Barbary Lesisz (Warszawa 1988), a wspólnie z Komisją Bibliograficzną Akademii Teologii Katolickiej w Warszawie stworzono Informator bibliograficzny obejmujacy zestaw ukazującej się w Polsce literatury z zakresu teologii, historii Kościoła i filozofii chrześcijańskiej. Zadaniem wspomnianej Komisji było

zorganizowanie warsztatu badawczego i kierowanie pracami nad przygotowaniem polskiej bibliografii teologii i prawa kanonicznego do 1968 roku oraz opracowanie bibliografii bieżącej tychże przedmiotów od 1969 roku² .

Dzięki jej staraniom powstały dwa tomy bibliografii retrospektywnej teologii i prawa kanonicznego za lata 1940-1968, podjęto bibliografię bieżącą, bibliografię biblistyki, historii Kościoła w Polsce za lata 1940-1970 oraz filozofii chrześcijańskiej (co znajduje odzwierciedlenie w elektronicznych bazach udostępnianych przez Bibliotekę Główną Uniwersytetu Kardynała Stefana Wyszyńskiego w Warszawie).

W literaturze przedmiotu można odnaleźć także informacje o realizowanych w przeszłości pracach bibliograficznych w postaci elektronicznej. Przykładowo w Bibliotece Archidiecezjalnego Wyższego Seminarium Duchownego w Białymstoku stworzono bibliografię zawartości „Studiów Teologicznych”27. W Bibliotece Papieskiego Wydziału Teologicznego i Metropolitalnego Wyższego Seminarium Duchownego we Wrocławiu opracowywano cztery bazy - bibliografie zawartości wydawnictw ciągłych, a mianowicie: WROBIT - Wrocławską Bibliografię Teologiczną („Wrocławski Przegląd Teologiczny”, „Colloquium Salutis” i prace zbiorowe; w 2007 roku ok. 2600 rekordów), Communio (dwumiesięcznik o tym samym tytule oraz seria „Kolekcja Communio”; w 2007 roku ok. 2060 rekordów), Wrocławskie Wiadomości Kościelne (od 1945 roku; 1870 rekordów w 2007 roku) oraz Homo Meditans (tytułowa seria Katolickiego Uniwersytetu Lubelskiego z 548 rekordami w 2007 roku) ${ }^{28}$. Wroctawskie Wiadomości Kościelne są obecne w multiwyszukiwarce FIDKAR, ale baza nie jest uzupełniana od czerwca 2010 roku. W tym samym roku zaprzestano aktualizacji Polskiej Bibliografii Pneumatologicznej 1946-2004 - narzędzia Federacji. Inną bazą w tej multiwyszukiwarce był w przeszłości Stefan Kardynat Wyszyński-fragment.

W innej z bibliotek seminaryjnych - Bibliotece Wyższego Seminarium Duchownego w Przemyślu - powstawała z kolei Bibliografia Archidiecezji Przemyskiej, a w Bibliotece Wyższego Seminarium Duchownego w Kielcach - Baza

Archiwum Kapituły Kolegiackiej i Katedralnej w Sandomierzu XIII-XX wieku (Sandomierz 2010) Feliksa Kiryka, Katalog druków XVI wieku Biblioteki Wyższego Seminarium Duchownego Metropolii Warmińskiej „Hosianum” w Olsztynie (Lublin cop. 2012) J. Wojtkowskiego, Nowy katalog dokumentów i listów Biblioteki Uniwersyteckiej KUL (Lublin 2012) Angeliki Modlińskiej-Piekarz, Druki z XVI-XVIII wieku w zbiorze Biblioteki Wyższego Seminarium Duchownego Misjonarzy Oblatów Maryi Niepokalanej w Obrze : katalog (Poznań 2016) Haliny Mieczkowskiej.

${ }^{26}$ R. Nir, Polskie bibliografie teologiczne, „Colloquium Salutis”, 4 (1972) s. 249.

${ }^{27}$ Olszewski, Biblioteka Archidiecezjalnego Wyższego Seminarium, s. 87.

${ }^{28}$ Szulc, Biblioteki Federacji Bibliotek Kościelnych, s. 10-11. 
Katechetyczna oraz Tytuly Zeszytów Znak ${ }^{29}$. Biblioteka Wyższego Seminarium Duchownego Towarzystwa Salezjańskiego w Lądzie tworzyła natomiast trzy bazy - Antiqua z zakresu patrologii, Baza Liturgiczna - z zakresu liturgiki oraz Hlond - opisy bibliograficzne materiałów poświęconych prymasowi Augustowi Hlondowi ${ }^{30}$. Biblioteka Wydziału Teologicznego Uniwersytetu Opolskiego opracowywała bazę o nazwie Opolska Bibliografia Teologiczna, która zawierała szczegółową bibliografię zawartości publikacji wydawanych przez Wydział Teologiczny Uniwersytetu Opolskiego. Były to czasopisma: „Liturgia Sacra”, „Scriptura Sacra”, „Studia Oecumenica” i „Studia Teologiczno-Historyczne Śląska Opolskiego” oraz prace z serii, m.in.: „Colloquia Theologica”, „Integracja i Ekumenizm”, „Opolska Biblioteka Teologiczna”, „Sympozja”, „Człowiek-Rodzina-Społeczeństwo” i „Z dziejów kultury chrześcijańskiej na Śląsku”31.

Pracę nad bibliografiami zawartości czasopism podjęto także w Bibliotece Głównej Uniwersytetu Papieskiego Jana Pawła II w Krakowie, gdzie rozpisywano w postaci bazy zawartość takich wydawnictw jak „Analecta Cracoviensa”, „Ruch Biblijny i Liturgiczny” oraz „Notificationes” ${ }^{32}$. Te publikacje, jak i bazy Communio, Homo Meditans, Wroctawska Bibliografia Teologiczna i Opolska Bibliografia Teologiczna nie zniknęły z przestrzeni wirtualnej, ale stały się częścią Elektronicznej Bibliografii Nauk Teologicznych.

\section{Bibliografie dziedzin i zagadnieńn ${ }^{33}$}

Elektroniczna Bibliografia Nauk Teologicznych (dalej: EBNT) jest najważniejszym produktem bibliograficznym bibliotek należących do „Fides”. Największy wpływ na kształt i zawartość bazy mają pracownicy Biblioteki Papieskiego Wydziału Teologicznego i Metropolitalnego Wyższego Seminarium Duchownego we Wrocławiu oraz jej dyrektor, ks. Jerzy Witczak ${ }^{34}$.

Prace nad polską bibliografią nauk teologicznych i kościelnych o charakterze bieżącym (z retrospektywnymi uzupełnieniami) rozpoczęto już wiele lat temu, ale wstrzymano w 1979 roku, by kontynuować dopiero od 2004. Energiczne działania podjęto w 2010 roku, po podpisaniu 25 października listu intencyjnego w sprawie współtworzenia narzędzia przez Bibliotekę Narodową w Warszawie i Federację. Od tego momentu baza zaczęła się zapełniać rekordami uzyskanymi z Zakładu Bibliografii Zawartości Czasopism Biblioteki Narodowej, który nieodpłatnie przekazywał opisy bibliograficzne tekstów pochodzących z wybranych

${ }^{29}$ Tamże, s. 11-12.

${ }^{30}$ Tamże, s. 11.

${ }^{31}$ T. Grabuńczyk, Historia komputeryzacji Biblioteki Wydziatu Teologicznego Uniwersytetu Opolskiego, „Fides. Biuletyn Bibliotek Kościelnych”, (2009) nr 1-2 (28-29), s. 23.

${ }^{32}$ Szulc, Biblioteki Federacji Bibliotek Kościelnych, s. 9.

${ }^{33}$ Do października 2019 roku na stronie WWW Biblioteki Teologicznej Uniwersytetu Śląskiego w Katowicach działał rejestr zatytułowany Artykuły o Bibliotece pod adresem: http://www.bt.us. edu.pl/index.php?option $=$ com_content\&view $=$ article \&id=165:artykuy-o-bibliotece\&catid=226\&Itemid $=206$.

${ }^{34}$ Por. analizę: Muc, Elektroniczna Bibliografia Nauk Teologicznych, s. 302-304, 306-311. 
przez Federację czasopism z lat 1996-2011 i nowo tworzone ${ }^{35}$. Uzyskane w ten sposób dane znacznie wzbogaciły zawartość bazy i w roku 2011 rozpoczęto prace nad umieszczeniem jej w sieci. Oficjalnie EBNT została uruchomiona 2 kwietnia 2011 roku i liczyła wówczas 63000 rekordów, z których 10\% sporządzono w bibliotekach Federacji ${ }^{36}$. Baza uzupełniana jest kolejnymi rekordami przekazywanymi przez książnicę narodową, ale też biblioteki zrzeszone. Te ostatnie są odpowiedzialne za dostarczanie opisów pochodzących z prac zbiorowych oraz czasopism sprzed momentu zawarcia porozumienia z Biblioteką Narodową i takich, które nie są tam bibliografowane ${ }^{37}$. By umożliwić zasilenie EBNT rekordami współtworzonymi przez biblioteki „Fides”, powstaje ona w systemie Koha, który ułatwia opracowanie źródła z różnych lokalizacji ${ }^{38}$.

Obecnie w bazie indeksuje się zawartość ponad 520 prac zbiorowych, w tym ksiąg jubileuszowych, materiałów pokonferencyjnych i serii wydawniczych, oraz ponad 230 polskich periodyków z zakresu teologii, religioznawstwa, filozofii chrześcijańskiej, prawa kanonicznego - ogłaszanych przez uczelnie kościelne, wydziały teologiczne, kościelne instytucje naukowe (stan na 25 lutego 2020 roku ${ }^{39}$. Do rzadkości należy indeksowanie zawartości innych publikacji. Opisy w bazie obejmują materiały wydane od 1980 roku. Zasięg chronologiczny jest jednak przekraczany, gdy do bibliografii trafiają opisy artykułów z czasopism rozpisanych w całości, które ukazywały się przed tą datą (np. „Colloquium Salutis”, „Studia Gnesnensia”, „Studia Katechetyczne”). W EBNT można doszukać się, po ostatniej aktualizacji dokonanej 25 lutego 2020 roku, niemal 139000 opisów. Według statystyki z 2016 roku nieco ponad 16\% danych pochodzi z bibliotek członkowskich „Fides”, co świadczy o zmieniających się proporcjach udziału w bazie Biblioteki Narodowej i bibliotek kościelnych ${ }^{40}$.

Poza tą rosnącą na korzyść Federacji partycypacją, pozytywnie należy ocenić wybrany przed pięcioma laty system Koha ${ }^{41}$, który jest przyjaznym dla użytkowników narzędziem, pozwalającym nie tylko udostępniać opisy formalne publikacji, ale też powiązać ich konkretne elementy, co rozszerza możliwości prowadze-

${ }^{35}$ Witczak, Federacja Bibliotek Kościelnych, s. 15.

${ }^{36}$ Tenże, Funkcjonowanie centralnego serwisu, s. 177.

${ }^{37}$ Tenże, Federacja Bibliotek Kościelnych, s. 16.

${ }^{38}$ B. Warząchowska, Federacja Bibliotek Kościelnych FIDES w przeddzień jubileuszu 25-lecia, „Bibliotheca Nostra. Śląski Kwartalnik Naukowy”, (2014) nr 2 (36), s. 82.

${ }^{39}$ Aktualizacja danych, http://biblio.fides.org.pl/ (dostęp: 2.03.2020).

${ }^{40}$ Elektroniczna Bibliografia Nauk Teologicznych, https://www.fides.org.pl/index.php/bazy-on-line/bazy-centralne/59-elektroniczna-bibliografia-nauk-teologicznych (dostęp: 14.11.2019). W roku 2020 nie dodano jeszcze bardziej szczegółowych informacji o statystyce opisów bibliograficznych.

${ }^{41}$ Użytkownicy mogą stosować wyszukiwanie według dowolnie wpisanych haseł w polach: całość, tytuł, autor i temat. Ponadto, przy wyszukiwaniu zaawansowanym dostępna jest algebra Boole'a i ograniczenie wyników do dat wydania w określonym przedziale czasowym. Trzeci sposób szukania - „według haseł” - pozwala na wprowadzanie nazw imprez, ciał zbiorowych, geograficznych, tytułowych oraz ustawienie odpowiednich kontekstów: „zawiera”, ,zaczyna się od” i ,jest dokładnie". Liczbę wyświetlonych rekordów można dodatkowo modyfikować i ograniczać poprzez fasety (dostępność, autorzy, źródło, miejsca, chronologia, tematy, tytuły). 
nia kwerend (il.1). W bazie do rekordów dołączone są także abstrakty oraz linki do pełnych tekstów, co wzbogaca i uatrakcyjnia ją, czyniąc nie tylko narzędzie skierowujące, ale i ostateczny element wyszukiwawczy.

回 Widok standardowy 四 Widok ISBD

\section{Biblioteki kościelne na łamach „Bibliografii Analitycznej Bibliotekoznawstwa i Informacji} Naukowej. Piśmiennictwo zagraniczne" / Ewa Olszowy.

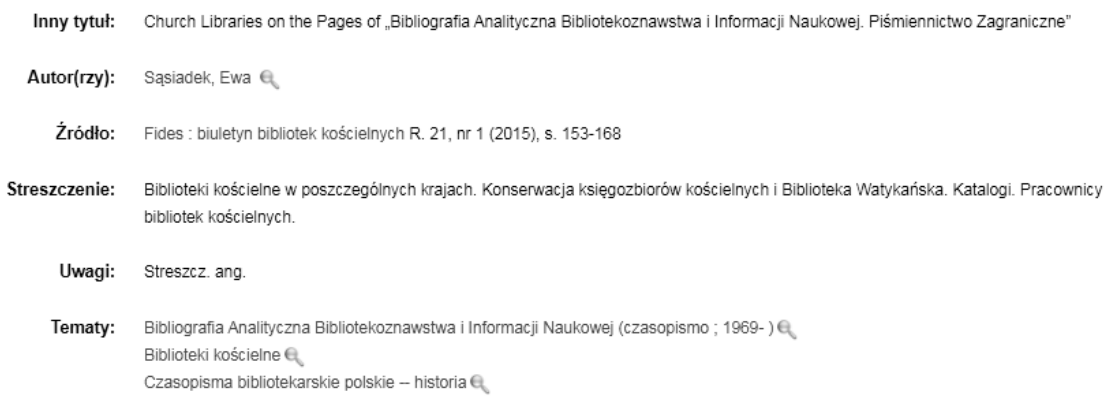

Il. 1. Przykładowy rekord z bazy Elektroniczna Bibliografia Nauk Teologicznych.

(Źródło: Elektroniczna Bibliografia Nauk Teologicznych, http://biblio.fides.org.pl/cgi-bin/koha/ opac-detail.pl?biblionumber=99851\&query_desc $=$ su $\% 2$ Cwrdl\%3A\%20bibliografia (dostęp: 14.11.2019)).

Omówiona baza stanowi kontynuację źródła opracowanego przez Bibliotekę Główną Uniwersytetu Kardynała Stefana Wyszyńskiego w Warszawie ${ }^{42}$, a mianowicie Polskiej Bibliografii Nauk Kościelnych 1940-1979, która funkcjonuje w postaci elektronicznej. Ta retrospektywna baza obejmuje piśmiennictwo z drukowanych wykazów wydanych przez Akademię Teologii Katolickiej, czyli z Polskiej bibliografii teologicznej za lata 1940-1948 o. Joachima Romana Bara i ks. Alfonsa Schletza (Warszawa 1969), Polskiej bibliografii teologii i prawa kanonicznego za rok... pod redakcją o. J.R. Bara (tomy za lata 1949-1970, Warszawa 1971-1972) oraz Polskiej bibliografii nauk kościelnych za rok... (za lata 1971-1979, Warszawa 1973-1986). W cyfrowej wersji zarejestrowano opisy publikacji z zakresu

nauk biblijnych, patrologii, teologii fundamentalnej, teologii dogmatycznej, teologii moralnej, teologii ascetycznej i mistycznej, teologii pastoralnej, homiletyki, katechetyki, liturgiki i prawa kanonicznego ${ }^{43}$.

Także kolejne narzędzie dostępne na stronie internetowej tej Biblioteki, a mianowicie Bibliografia Historii Kościoła 1944-1984, ma formę cyfrową drukowanej przez Akademię Teologii Katolickiej Bibliografii historii Kościoła w Polsce za lata ... w opracowaniu ks. Hieronima Wyczawskiego (Warszawa 1977-1997). Węższy zakres tematyczny reprezentuje trzecia już baza instytucji, przygotowana w latach 1993-2009 przez ks. Stanisława Warzeszaka, Bibliografia Teologii

${ }^{42}$ Por. informacje: Muc, Elektroniczna Bibliografia Nauk Teologicznych, s. 299-301.

${ }^{43}$ Polska Bibliografia Nauk Kościelnych 1940-1979, http://bazy.biblioteka.uksw.edu.pl/bnk. php (dostęp: 14.11.2019). 
Moralnej i Etyki ${ }^{44} \mathrm{z}$ opisami tekstów w języku polskim oraz autorów polskich bez względu na język, które wydano od XV do XXI wieku. Z kolei Polska Bibliografia Antyku Chrześcijańskiego - ostatnia już z baz Biblioteki - uwzględnia opisy źródeł ogłoszonych od 1990 roku w języku polskim oraz językach obcych (publikowane na terenie kraju oraz polskich autorów). Również i w tej bazie wykorzystano materiały drukowane, tym razem na łamach „Vox Patrum”, gdzie od 1995 roku ks. Józef Naumowicz i ks. Stanisław Longosz zamieszczali Polska bibliografię antyku chrześcijańskiego.

Wszystkie te narzędzia bibliograficzne zbudowano w systemie Expertus ${ }^{45}$. W wyświetlonych rekordach (niezbyt przyjazny sposób podawania danych bibliograficznych - il. 2) można odnaleźć hasła autorskie, tytułowe i rzeczowe $\mathrm{Z}$ odsyłaczami. $\mathrm{Z}$ pewnością ich użyteczność podniosłyby dołączone do opisów abstrakty oraz odnośniki do pełnych tekstów (zwłaszcza że bazy mają częściowo przynajmniej charakter retrospektywny).

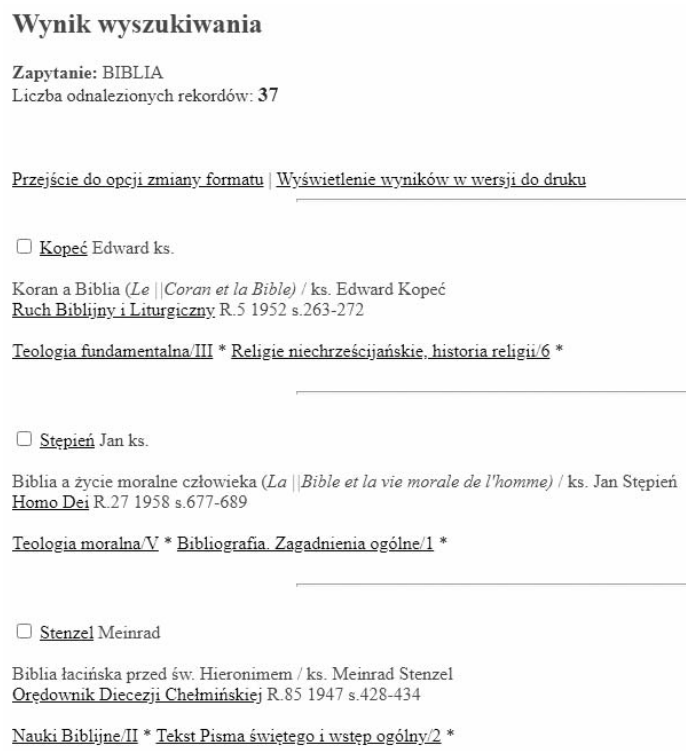

I1. 2. Przykładowe rekordy z bazy Polska Bibliografia Nauk Kościelnych 1940-1979.

(Źródło: Polska Bibliografia Nauk Kościelnych 1940-1979, http://bazy.biblioteka.uksw.edu.pl/ expertus.cgi (dostęp: 14.11.2019)).

${ }^{44}$ Baza ta dostępna jest także przez multiwyszukiwarkę FIDKAR łącznie z bazami Bibliografia Nauk Kościelnych (1940-1979), Bibliografia Historii Kościoła (1944-1984).

${ }^{45}$ Wyszukiwanie w dwóch pierwszych bazach odbywa się poprzez indeksy: osoba, tytuł, słowa w tytule, czasopismo, zagadnienie, dział, nazwa korporatywna, seria, wydawca, ISBN, numer pozycji w bibliografii, które można łączyć ze sobą dzięki zastosowaniu algebry Boole'a. W Bibliografii Teologii Moralnej i Etyki zaproponowano mniejszy wybór indeksów: autor, tytuł, seria, czasopismo, zagadnienie, teksty Pisma Świętego, słowa w tytule, język, a w Polskiej Bibliografii Antyku Chrześcijańskiego - zagadnienie; zagadnienie - dowolne słowa; tytuł - dowolne słowa; autor, redaktor, thumacz; autor korporatywny; tytuł - hasło; wydawca; seria; seria - dowolne słowa oraz dowolne słowa opisu. 
Na stronie internetowej Instytutu Tomistycznego w Warszawie, przy którym działa Biblioteka Instytutu Tomistycznego, udostępniono kolejną bibliografię retrospektywną o tytule Polska Bibliografia Tomistyczna. Obejmuje ona opisy literatury wydanej między 1879 a 2004 rokiem. Z charakterystyki bazy na stronie domowej (brak obecnie dostępu) ${ }^{46}$ można dowiedzieć się, że projekt powstał w 2003 roku z inicjatywy byłego dyrektora Instytutu Tomistycznego, o. Michała Palucha, a pracowali nad nim przez lata dominikańscy studenci oraz Magdalena Pabich, we współpracy z pracownikami Biblioteki Kolegium Filozoficzno-Teologicznego w Krakowie. Wyjątkowy charakter źródła wynika z wąskiego zakresu - włączane są opisy tekstów tomistycznych w ujęciu podmiotowo-przedmiotowym (polonika krajowe i zagraniczne) $\mathrm{i}$

W rezultacie w bibliografii zostały wykazane publikacje, których autorzy w tytule (lub podtytule) deklarowali wykład jakiegoś problemu „w świetle nauki św. Tomasza” albo „w świetle tomizmu”, natomiast pominięto artykuły i książki napisane przez autorów „powszechnie” zaliczanych do tomistów, które jednak w swych tytułach takich deklaracji nie mająa

Inne cechy ma kolejna baza opracowana przez Bibliotekę Wyższego Seminarium Duchownego Metropolii Warmińskiej „Hosianum” i Wydziału Teologii Uniwersytetu Warmińsko-Mazurskiego w Olsztynie. Warmińska Bibliografia Teologiczna ma charakter regionalny i obejmuje opisy częściowo adnotowane (adnotacje zawartościowe, il. 3) książek, rozdziałów w książkach, artykułów czasopiśmienniczych (liczy 1577 rekordów, stan na 14 listopada 2019 roku).

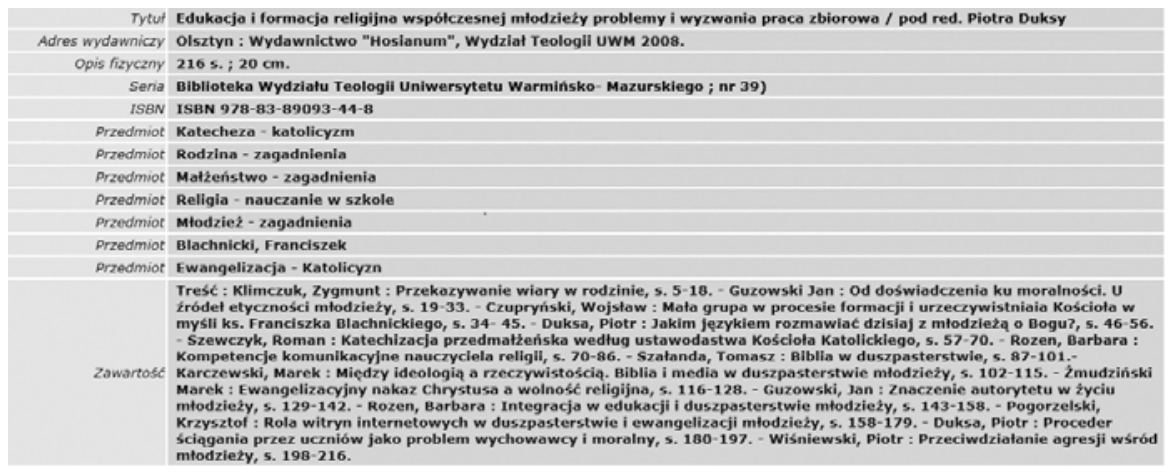

I1. 3. Przykładowy opis z bazy Warmińska Bibliografia Teologiczna.

(Źródło: Baza: WARMIŃSKA BIBLIOGRAFIA TEOLOGICZNA, http://213.73.25.158/cgi-bin/ makwww.exe?BM=06\&IM=03\&TX=\&NU=01\&WI=BIBLIA (dostęp: 14.11.2019)).

Odmienny od wcześniej przedstawionych projektów bibliograficznych jest ten podjęty przez Bibliotekę Warszawskiej Prowincji Zakonu Braci Mniejszych Kapucynów w Zakroczymiu, która udostępnia liczącą zaledwie 14 opisów bibliograficznych Bibliografię Honoracka.

${ }^{46} \mathrm{Z}$ komunikatu wynika, że trwają prace nad nową wersją bazy.

${ }^{47}$ Polska Bibliografia Tomistyczna, https://www.it.dominikanie.pl/projekty-it/polska-bibliogr-tomist/ (dostęp: 14.11.2019). 
Dwie ostatnie zaprezentowane bazy utrzymywane są w systemie MAKWWW ${ }^{48}$.

Z przeglądu wynika, że Federacja jest odpowiedzialna za tworzenie przede wszystkim naukowego narzędzia dla teologów i osób zainteresowanych naukami kościelnymi. Jest ono uzupełniane opisami powstającymi w wielu bibliotekach FIDES, o czym będzie jeszcze mowa. Natomiast tylko nieliczne placówki opracowują samodzielnie bibliografie dziedzinowe, zazwyczaj o charakterze retrospektywnym, co może oczywiście wynikać z zaangażowania w proces przygotowania EBNT.

\section{Bibliografie czasopism i bibliografie zawartości czasopism}

Bibliografie zawartości wydawnictw ciągłych są domeną bibliotek diecezjalnych seminariów duchownych, będących wydawcami periodyków ${ }^{49}$. Największym twórcą takich narzędzi jest Biblioteka Wyższego Seminarium Duchownego w Kielcach, na której stronach można odnaleźć sześć niezależnych baz, obejmujących następujące czasopisma: „Przegląd Diecezjalny” z kontynuacją „Kielecki Przegląd Diecezjalny” (1911-2012) i odrębnie „Kielecki Przegląd Diecezjalny” (od 2013 roku), „Przegląd Homiletyczny” (1923-1939) z kontynuacją o tym samym tytule, „Współczesna Ambona” (od 1946 roku, z kilkoma przerwami) oraz „Kieleckie Studia Teologiczne” (od 2002 roku) ${ }^{50}$. Wydawcami tych czasopism były w przeszłości lub są współcześnie Kuria Diecezjalna w Kielcach, Kieleckie Koło Homiletyczne, Wyższe Seminarium Duchowne w Kielcach i Wydawnictwo „Jedność”. Kieleckie bazy różnią się znacznie liczbą opisów - największą jest ta o nazwie Przegląd Diecezjalny / Kielecki Przegląd Diecezjalny 1911-2012 z 12846 rekordami, a najmniejszą, liczącą 315 opisów, Przegląd Homiletyczny (stan na 9 listopada 2019 roku). Część czasopism ma charakter naukowy, dlatego włączono ich zawartość do EBNT. Pozostała grupa periodyków ogłaszana była i jest przez organy diecezjalne, więc można z nich skorzystać jedynie na stronie internetowej Biblioteki. Zasada przekazywania rekordów z organów naukowych do wspomnianej bazy obowiązuje we wszystkich pozostałych ośrodkach publikujących elektroniczne bibliografie zawartości czasopism.

Podobnego charakteru narzędzia oferuje użytkownikom Biblioteka Wyższego Metropolitalnego Seminarium Duchownego św. Jana Chrzciciela w Warszawie, ogłaszając: Wiadomości Archidiecezjalne Warszawskie oraz Warszawskie Studia Teologiczne. Pierwsza baza liczy 8679 opisów, podczas gdy druga 407 (stan na 9 listopada 2019 roku). „Wiadomości Archidiecezjalne Warszawskie” ukazują się od 1911 roku (z przerwą w okresie II wojny światowej) jako wydawnictwo Kurii

${ }^{48}$ Pierwszą z baz można przeszukiwać za pomocą indeksu autorskiego, tytułowego, słów w tytule, serii, wydawców i przedmiotowego. Tak jak i w przypadku innych baz makowskich istnieje sposobność wyszukiwania zaawansowanego na dwa sposoby. W Bibliografii Honorackiej rozbudowano indeksy: autor, tytuł, słowo w tytule, rok wydania, wydawca, miejsce wydania, język tekstu, rzeczowy, dokument macierzysty.

${ }^{49} \mathrm{Na}$ stronie internetowej Biblioteki Wyższego Seminarium Duchownego w Przemyślu teoretycznie tylko dostępna jest Bibliografia Niedzieli Przemyskiej.

${ }^{50}$ Był kontynuacją międzywojennego czasopisma o tym samym tytule oraz publikowanego w latach 1997-2000 „Przeglądu Pastoralno-Homiletycznego”. 
Metropolitalnej Warszawskiej, a obecnie czasopismo urzędowe, półrocznik duchowieństwa Archidiecezji Warszawskiej. Drugie z czasopism jest organem Papieskiego Wydziału Teologicznego w Warszawie i ukazuje się od 1983 roku.

Po jednej bazie zawartości opracowują też inne biblioteki seminaryjne. W Bibliotece Prymasowskiego Wyższego Seminarium Duchownego w Gnieźnie rozpisuje się zawartość Studiów Gnesnensia (231 rekordów z lat 1975-1990, stan na 9 listopada 2019 roku), czasopisma Seminarium Duchownego w Gnieźnie od 1936 roku. Czasopismo ukazywało się do momentu wybuchu II wojny światowej, a wznowiono je w roku 1975, by od 1997 wydawać regularnie w postaci rocznika. Nieco mylący tytuł nosi z kolei baza Biblioteki Wyższego Seminarium Duchownego Diecezji Koszalińsko-Kołobrzeskiej. Pod nazwą Czasopisma diecezjalne nie kryje się bowiem wykaz periodyków ogłaszanych przez diecezję lub na jej terenie, ale bibliografia zawartości dwóch czasopism diecezjalnych - „Studiów Koszalińsko-Kołobrzeskich” i „Rocznika Skrzatuskiego”. Pierwsze z nich, publikowane od 1992 roku, jest rocznikiem Wydziału Teologicznego Uniwersytetu Szczecińskiego, redagowanym przez Wyższe Seminarium Duchowne Diecezji Koszalińsko-Kołobrzeskiej. „Rocznik Skrzatuski” został z kolei powołany do życia w Roku Skrzatuskim, 2013, z okazji dwudziestopięciolecia koronacji Piety Skrzatuskiej jako dzieło Biblioteki Wyższego Seminarium Duchownego Diecezji Koszalińsko-Kołobrzeskiej. Bibliografia Wiadomosci_Lomza opracowywana jest natomiast przez Bibliotekę Wyższego Seminarium Duchownego w Łomży i jest to rejestr zawartości „Łomżyńskich Wiadomości Diecezjalnych”, wydawanych od 1986 roku, a będących kontynuacją „Rozporządzeń Urzędowych Łomżyńskiej Kurji Diecezjalnej” (1933-1985), „Rozporządzeń Urzędowych Kurji Biskupiej Łomżyńskiej” (1929-1932) i „Wiadomości Kościelnych Diecezji Łomżyńskiej” (1927-1928). Tak więc baza obejmuje treść czterech periodyków.

Wszystkie wymienione bibliografie utrzymywane są w programie MAKWWW i wykazują duże podobieństwa, gdy idzie o możliwości wyświetlania danych (il. 4) oraz ich przeszukiwanie (poza indeksami ${ }^{51}$ dostępne są dwa sposoby wyszukiwania zaawansowanego).

${ }^{51}$ Kieleckie bazy można przeglądać poprzez indeksy - przy czym dla każdej z baz są one odmiennie zdefiniowane (przykładowo: rzeczowy, autorski, tekstów Pisma Świętego, tytułowy, słów w tytule, cykli, nota-czas - odsyła do opisów artykułów zawartych w konkretnych numerach czasopisma, temat-określnik, hasło przedmiotowe, tytułów czasopism, dat, recenzji, serii). W warszawskich źródłach zastosowano indeksy: rzeczowy, słowa w tytule, autorski, czasopism i tekstów Pisma Świętego. Bazę Studia Gnesnensia przeszukuje się za pomocą indeksów: językowego, autorskiego, czasopism, tytułowego, rzeczowego, słów w tytule oraz kodów, serii (dwa ostatnie indeksy puste), a Czasopisma diecezjalne: tytułowego czasopism, serii, numeru tomu, autorskiego tytułowego, słowa w tytule, numeru kontrolnego rekordu, temat - określnik, hasło przedmiotowe oraz rok - miesiąc (przy czym po jego otworzeniu pojawiają się numery rekordów odnotowanych w „Bibliografii Zawartości Czasopism"). W łomżyńskiej bibliografii wyodrębniono indeksy: autorski, rzeczowy, tekstów z Pisma Świętego, słów w tytule, czasopism oraz prac zbiorowych (indeks pusty). 


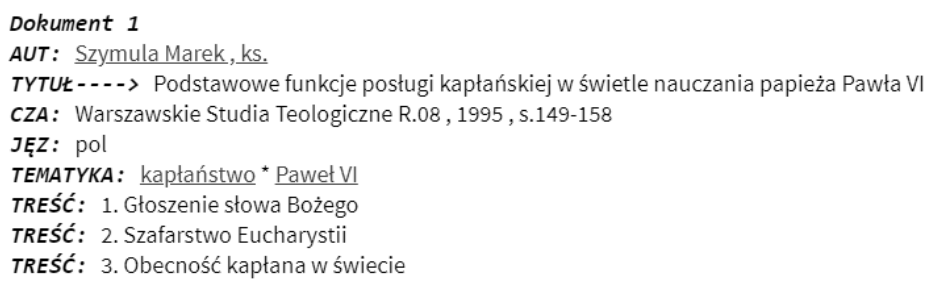

Dokument 2

AUT: Szymula Marek, ks.

TYTUt - - - -> Fundamentalne elementy duchowości kapłańskiej w świetle nauczania papieża Pawła VI

CZA: Warszawskie Studia Teologiczne R.10, 1997, s.367-378

JEZZ: pol

TEMATYKA: duchowość kapłańska * Paweł VI

TREŚĆ: 1. Duchowość budowana na sakramentalności święceń

TREŚĆ: 2. Duchowość budowana na relacji biskup - prezbiter

TREŚĆ: 3. Duchowość budowana na pracy pastoralnej

Il. 4. Zrzut ekranu z bazy Warszawskie Studia Teologiczne z podlinkowanymi hasłami.

Źródło: Baza: WARSZAWSKIE STUDIA TEOLOGICZNE, http://makwww.wmsd.waw.pl/ makwww.exe?BM=07\&IM=01\&TX=\&NU=04\&WI=PAWElbAPOSTO1, (dostęp: 9.11.2019).

W zdecydowanej większości baz brakuje prostego choćby opisu, pozwalającego użytkownikom zapoznać się z ich zakresem, zasięgami czy krótką charakterystyką indeksowanych czasopism. Brakuje systemu podpowiedzi i wyjaśnień dotyczących np. zawartości poszczególnych indeksów. Stworzenie takiego aparatu pomocniczego z pewnością przysłużyłoby się przeszukującym bazy. Uwaga to dotyczy w zasadzie już tylko baz obejmujących zawartość czasopism diecezjalnych, ponieważ pozostałe przeniesiono do EBNT. Jednak na stronie internetowej bibliotek, co trzeba wyraźnie podkreślić, znajdują się bazy, które obejmują mniejszą liczbę opisów artykułów niż liczba opisów z tych samych czasopism w bibliografii dziedzinowej.

Odmienny charakter ma ostatnia charakteryzowana bibliografia, dostępna na stronie Biblioteki Towarzystwa Chrystusowego dla Polonii Zagranicznej im. ks. Jana Jabłońskiego TChr w Poznaniu, o nazwie Czasopisma polonijne, tworzona od 2009 roku. Biblioteka dysponuje imponującym zbiorem otrzymanej w latach 80. XX wieku kolekcji polonijnych periodyków gromadzonych przez dziesiątki lat przez Jana Kowalika, działacza i bibliografa. Z uwagi na uwarunkowania polityczne zasób trafił do Polski dopiero po 1989 roku - i od tego momentu jest sukcesywnie opracowywany.

Udostępniony w formacie HTML spis nie jest typową bazą - brakuje systemu przeszukiwania opisów. Zostały one ułożone według nazw kontynentów, a w ich obrębie - nazw krajów ${ }^{52}$. Po wybraniu nazwy kontynentu i państwa, ukazuje się

${ }^{52}$ Europa (Albania - link pusty, Austria, Belgia, Białoruś, Bośnia i Hercegowina - brak odnośnika, Bułgaria, Chorwacja - odnośnik pusty, Cypr, Czechy, Dania, Estonia, Finlandia, Francja, Grecja, Gruzja, Hiszpania, Holandia, Irlandia, Islandia, Palestyna/Izrael, Litwa, Łotwa, Luksemburg, Mace- 
spis przypisanych do danego terytorium czasopism, w podziale na te, które znajdują się w Bibliotece - z sygnaturą, oraz „listę orientacyjną” (Il. 5). Po części zatem bibliografia wydawnictw ciągłych pełni rolę katalogu, jednak bez możliwości automatycznego zamówienia pozycji.

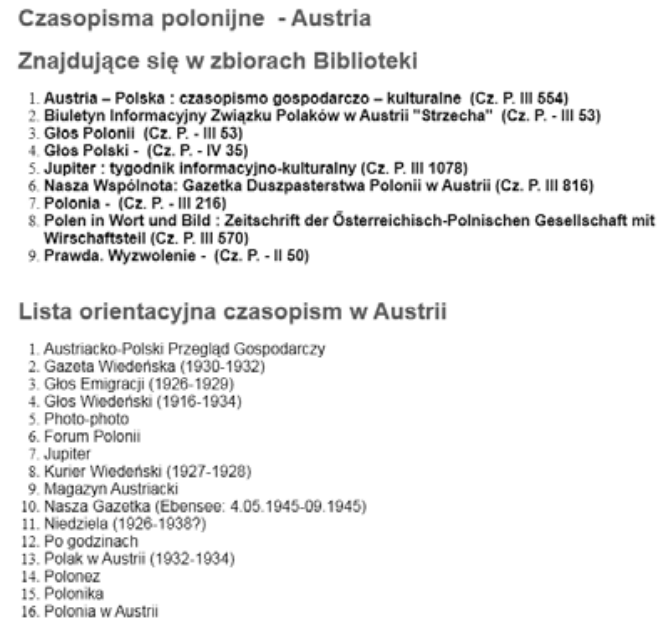

Il. 5. Wykaz czasopism polonijnych w Austrii z bazy Czasopisma polonijne.

(Źródło: Czasopisma polonijne - Austria, http://www.biblioteka.chrystusowcy.pl/Czasopisma\%20 polonijne\%20Austria.htm (dostęp: 12.11.2019)).

\section{Bibliografie osobowe i zespolów osobowych ${ }^{53}$}

Jedyną bibliografię osobową udostępnia „Fides”. Jest to licząca 38157 opisów (stan na 18 listopada 2019 roku) Jan Pawet II. Bibliografia polska 19491997. Spis podmiotowo-przedmiotowy powstał na podstawie dziewięciu tomów drukowanych od 1980 roku przez Fundację Jana Pawła II - Ośrodek Dokumen-

donia, Mołdawia, Niemcy, Norwegia, Polska, Portugalia, Rosja, Rumunia, Serbia, Serbia-Czarnogóra - brak odnośnika, Słowacja, Słowenia - link pusty, Szkocja, Szwajcaria, Szwecja, Turcja, Ukraina Węgry, Wielka Brytania, Włochy), Azja (Armenia, Azerbejdżan - brak odnośnika, Chiny, Emiraty Arabskie - brak odnośnika, Gruzja-Abchazja - brak odnośnika, Hongkong - brak odnośnika, Indie, Indonezja - brak odnośnika, Iran, Japonia, Jemen - brak odnośnika, Kazachstan, Kirgistan - brak odnośnika, Kuwejt - brak odnośnika, Liban, Turkmenistan - brak odnośnika, Uzbekistan - brak odnośnika), Afryka (Angola - brak odnośnika, Egipt, Kamerun - brak odnośnika, Kenia, Libia, Mozambik - brak odnośnika, Republika Południowej Afryki, Syria, Tanzania - brak odnośnika, Zambia brak odnośnika, Zimbabwe), Ameryka Południowa (Argentyna, Brazylia, Chile, Dominikana - brak odnośnika, Ekwador - brak odnośnika, Gwatemala - brak odnośnika, Honduras - brak odnośnika, Jamajka - brak odnośnika, Kolumbia - brak odnośnika, Kostaryka - brak odnośnika, Kuba, Nikaragua - brak odnośnika, Panama - brak odnośnika, Paragwaj - brak odnośnika, Peru, Salwador - brak odnośnika, Urugwaj, Wenezuela), Ameryka Północna (Kanada, Meksyk, Stany Zjednoczone - najdłuższy wykaz), Australia (Australia, Nowa Zelandia, Papua Nowa Gwinea).

${ }^{53}$ Do października 2019 roku na stronie WWW Biblioteki Teologicznej Uniwersytetu Śląskiego w Katowicach działał wykaz o tytule Bibliografia pracowników pod adresem: http://www.bt. us.edu.pl/index.php?option=com_content\&view=article\&id=275:bibliografia=-pracownikow\&catid226\&Itemid $=206$. 
tacji Pontyfikatu w Rzymie. W październiku 2011 roku został dodany do systemu źródeł katalogowo-bibliograficznych Federacji ${ }^{54}$. Zgromadzono w nim opisy dokumentów i wypowiedzi Jana Pawła II oraz prace o nim, które ogłoszono na terenie Polski, także w językach obcych. Nie uwzględnia się natomiast poloników zagranicznych, z wyjątkiem tych, których recenzje ukazały się w kraju. Odnotowano różne typy dokumentów, w tym druki zwarte i ciągłe, utwory i ich fragmenty, odbitki, kalendarze itp. Baza utrzymywana jest w systemie MAKWWW ${ }^{55}$.

$\mathrm{W}$ bibliotekach zrzeszonych powstają z kolei bibliografie zespołów osobowych. Są one charakterystyczne przede wszystkim dla bibliotek akademickich, które są odpowiedzialne za prace związane $\mathrm{z}$ tworzeniem bibliografii dorobku publikacyjnego pracowników uczelni czy wydziałów. Przykładowo, bibliotekarze Biblioteki Wydziału Teologicznego Uniwersytetu Mikołaja Kopernika w Toruniu współpracują z Sekcją Bibliografii Publikacji Pracowników UMK i Analiz Bibliometrycznych Biblioteki Głównej i od 2010 roku wpisują dane do Bibliografii publikacji pracowników, doktorantów i studentów Uniwersytetu Mikołaja Kopernika $w$ Toruniu $\mathrm{w}$ systemie Expertus ${ }^{56}$. Stanowi ona narzędzie służące promocji dorobku, ale też podstawę do oceny pracowników i jednostki naukowej ${ }^{57}$ (Il. 6).

${ }^{54}$ J. Witczak, Funkcjonowanie centralnego serwisu, s. 177.

${ }^{55}$ Jej zawartość można przejrzeć dzięki indeksom: autor, tytuł, słowo, przedmiot, temat/określnik, czasopismo, wydawca, data wydania, rok, tom (drukowanej wersji) oraz z zastosowaniem dwóch sposobów wyszukiwania zaawansowanego.

${ }^{56}$ Początkowo powstała baza w programie CDS/ISIS, by w 2005 roku przekonwertować ją do obecnego narzędzia. Jest ona - jak w większości przypadków gdy mowa o bibliografiach tego typu kontynuacją drukowanych spisów (zasięg chronologiczny od roku 1986). Bazę można przeszukiwać na kilka sposobów. Najprostszym z nich jest wybór indeksu. Zdefiniowane zostały następujące: autor, autor i jednostka, tytuł, tytuł - słowa, słowo kluczowe angielskie, słowo kluczowe polskie, źródło, źródło - słowa, czasopismo, seria, seria - słowa, miejsce wydania, wydawnictwo, typ formalny dokumentu - kod, typ formalny dokumentu - nazwa, typ merytoryczny dokumentu - kod, typ merytoryczny dokumentu - nazwa, typ opi dokumentu - kod, typ opi dokumentu - nazwa, wydział - skrót, wydział, jednostka organizacyjna - skrót, jednostka organizacyjna, język publikacji, ISBN, ISSN, dowolne słowa z opisu, bazy bibliograficzne. W wyszukiwaniu można też zastosować algebrę Boole'a. Chcąc ograniczać wyniki poszukiwań można skorzystać z filtrów, jak wybór pojedynczych roczników, opisów afiliowanych, prac z punktacjami ISI Master Journal List, Journal Citation Reports - lub bez nich, języka publikacji, dostępności w sieci. Użytkownik może także zdefiniować format wyświetlania danych i sposób szeregowania oraz zamaskować część wyszukiwanej frazy.

${ }^{57}$ K. Burnicka, Biblioteka Wydziału Teologicznego Uniwersytetu Mikotaja Kopernika w Toruniu. Zarys problematyki, „Fides. Biuletyn Bibliotek Kościelnych”, 23 (2017) nr 2 (45), s. 67. 


\section{Wynik wyszukiwania}

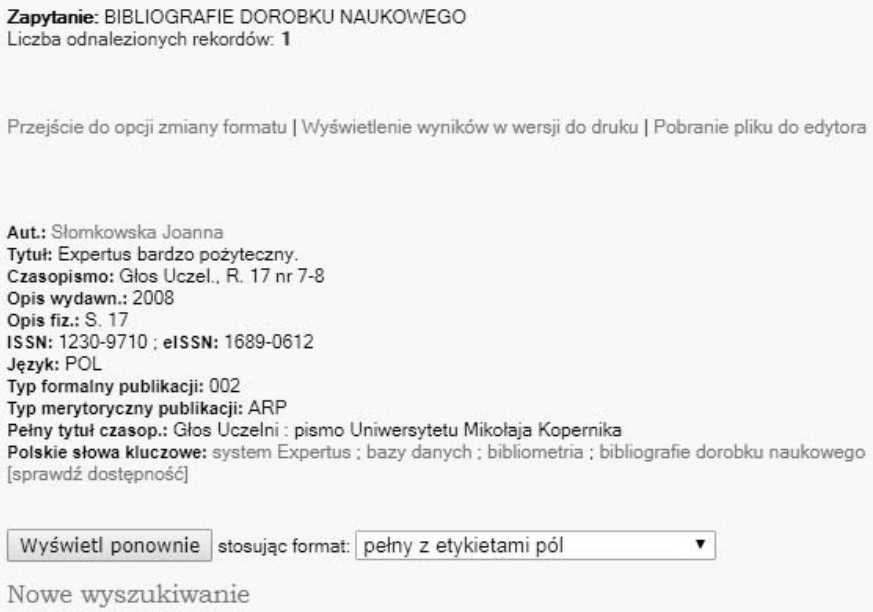

I1.6. Przykładowy rekord z bazy Bibliografia publikacji pracowników, doktorantów i studentów Uniwersytetu Mikolaja Kopernika w Toruniu.

(Źródło: Wynik wyszukiwania, http://bg.cm.umk.pl/scripts/splendor/expert4e.exe (dostęp: 12.11.2019)).

Kolejnymi bibliotekami współtworzącymi bibliografie zespołów osobowych są Biblioteka Kampusowa Papieża Pawła VI TEO. Filia Biblioteki Głównej Uniwersytetu Szczecińskiego wspomagająca powstanie Bazy Publikacji Pracowników US (w systemie Koha) oraz Biblioteka Teologiczna Uniwersytetu Śląskiego w Katowicach - Bibliografii Dorobku Pracowników UŚ (w systemie PROLIB). Z kolei na stronie internetowej Biblioteki Wydziału Teologicznego Uniwersytetu Opolskiego można odnaleźć odnośnik do Bazy Wiedzy Uniwersytetu Opolskiego, której celem jest upowszechnianie dorobku pracowników uczelni, a na stronie WWW Katolickiego Uniwersytetu Lubelskiego Jana Pawła II w zakładce Nauka można znaleźć sekcję Publikacje, pod którą kryje się baza danych twórczości badaczy reprezentujących jednostkę.

Gdy mowa o rejestrach dorobku piśmienniczego osób, to należy jeszcze wspomnieć o kolejnej już bibliografii Biblioteki Towarzystwa Chrystusowego dla Polonii Zagranicznej im. ks. Jana Jabłońskiego TChr w Poznaniu, która w jednej z zakładek ukazuje Publikacje Chrystusowców. Po wejściu na stronę internetową pojawia się wykaz czternastu nazwisk, z czego przy dziesięciu po kliknięciu na nazwę rozwija się spis tekstów autorstwa danej osoby w formacie PDF. Bywa, że przy nazwisku podana jest data urodzenia lub daty życia, a poniżej zestawiono rejestr (opisy nieznormalizowane, ale odzwierciedlające podstawowe dane o dokumencie), czasami dzielony na typy wypowiedzi: książki, artykuły (naukowe, popularnonaukowe i popularne), redakcja książek, hasła (słownikowe i encyklopedyczne), thumaczenia, recenzje, inne opracowania, ale też prelekcje i wystąpienia, wypromowane prace magisterskie, a nawet nazwy prowadzonych zajęć 
dydaktycznych. Nie jest to zatem - tak jak i w przypadku spisu czasopism polonijnych - typowa baza danych, a jedynie zbiór niepowiązanych nawet metodycznie wykazów publikacji chrystusowców.

Inną jeszcze formą bibliografii zespołu osobowego jest taki, w którym promowana jest twórczość publikacyjna pracowników książnicy. Przykładem jest wykaz o nazwie Publikacje pracowników Biblioteki, który zamieszczono na stronie internetowej Biblioteki Głównej Uniwersytetu Kardynała Stefana Wyszyńskiego w Warszawie. W formacie HTML ogłoszono liczący łącznie 51 opisów bibliograficznych rejestr, podzielony na trzy części: Publikacje pracowników, Ttumaczenia Marii Elżbiety Kowalskiej oraz Publikacje byłych pracowników, wśród których wyszczególniono Publikacje dr hab., prof. UKSW, KATARZYNY MATERSKIEJ publikacje od 2013 r. i Publikacje mgr P. Latawca. Także i to zestawienie opisów nie stanowi bazy danych.

\section{Zakończenie}

W bibliotekach zrzeszonych w Federacji działalność bibliograficzną poszerza się o udostępniane na stronach internetowych bibliograficzne bazy danych. Jedną z częściej polecanych jest indeks bibliograficzny ATLA Religion Database. Do źródeł propagowanych należą także te tworzone przez samą Federację i Bibliotekę Główną Uniwersytetu Kardynała Stefana Wyszyńskiego w Warszawie, ponadto bazy katalogowe i bibliograficzne Biblioteki Narodowej w Warszawie, Index Theologicus, Alcuinus. Online Liturgical Bibliography i inne. Przodują w tym zakresie biblioteki akademickie, oferujące swoim użytkownikom wiele komercyjnych baz dziedzinowych. One też wspomagają pracowników, doktorantów i studentów oferując narzędzia do zarządzania danymi bibliograficznymi (cytowaniami i bibliografiami załącznikowymi), jak menedżery bibliografii (Citavi, Mendeley, EndNote, Zotero, RefWorks, Papers) oraz generatory bibliografii (CiteThisForMe, EasyBib, Bibsonomy, Harvard Generator, Neil's Toolbox, Calvin, Citation Machine).

Podsumowując aktywność bibliograficzną bibliotek „Fides” trzeba zaznaczyć, że bazy bądź rejestry przygotowuje lub przygotowywało $18,75 \%$ instytucji reprezentujących cztery spośród dziesięciu typów zrzeszonych książnic. Wynik ten może nie jest imponujący, ale biblioteki należące do organizacji - poza akademickimi - nie są w żaden sposób zobligowane do podejmowania prac bibliograficznych. Analizując udział poszczególnych kategorii książnic w opracowaniu baz danych, czyli odpowiadając na postawione na wstępie pytanie o realny ich wkład do projektów bibliograficznych, zauważa się, że najmocniej zaangażowane, w 100\%, są biblioteki wydziałowe oraz 33,33\% bibliotek uczelni wyższych. W obu typach instytucji powstają te same rodzaje bibliograficznych baz lub spisów: bibliografie dziedzinowe $(57,14 \% \mathrm{w}$ bibliotekach wszechnic, a $14,29 \% \mathrm{w}$ wydziałowych) oraz zespołów osobowych $(57,14 \% \mathrm{w}$ bibliotekach wydziałów, a $28,57 \% \mathrm{w}$ uczelnianych) - choć w odmiennych proporcjach. Jest to wynik realizowanych przed laty prac nad retrospektywnymi lub bieżącymi źródłami informacji oraz aktualnej praktyki, polegającej na sporządzaniu podstaw do oceny dokonań publikacyjnych pracowników naukowych i zatrudniających je jednostek. 
Z bibliotek seminariów duchownych diecezji $20 \%$ bierze udział w pracach bibliograficznych, których wynikiem jest aż 91,67\% wszystkich zanalizowanych bibliografii zawartości czasopism - zazwyczaj tych tytułów, których wydawcami były lub są organy diecezjalne lub seminaria. Niewiele mniejsze jest uczestnictwo książnic działających przy zakonach męskich, z których 18,75\% tworzy bibliografie. Ich pracownicy sporządzają źródła wszystkich typów. Mają wkład w 28,57\% bibliografii dziedzinowych, 14,29\% bibliografii zespołów osobowych oraz $8,33 \%$ bibliografii czasopism i ich zawartości.

Łącznie, w piętnastu badanych instytucjach, stworzono lub współtworzono 26 źródeł, z czego niemal połowę, bo 46,16\% stanowią bibliografie czasopism i ich zawartości, a po $26,92 \%$ - bibliografie dziedzinowe i zespołów osobowych. Trzeba podkreślić, że akademicki charakter bibliotek wpływa na inicjatywy bibliograficzne, bowiem organizatorami omówionych serwisów w $80 \%$ są biblioteki instytucji, w których uprawia się badania naukowe i dydaktykę. Znaczącą pozycję w tej grupie zajmują biblioteki seminariów duchownych diecezji, ale jak wskazano w artykule, część inicjatyw, w postaci bibliografii zawartości czasopism, nie jest już aktualizowana na stronach internetowych konkretnych instytucji. Pracownicy tych książnic angażują się obecnie w EBNT. Prace bibliograficzne będą w nich zapewne nadal prowadzone, ale wynikiem międzyinstytucjonalnych działań bibliotek „Fides” - co już teraz można zauważyć - w coraz większym stopniu będzie bibliografia dziedzinowa, a nie indywidualnie opracowywane i udostępniane bazy.

$E B N T$ mogłaby pełnić funkcję fundamentalnego źródła informacji bieżącej i retrospektywnej, gdyby rozszerzono jej zasięg formalny o wydawnictwa zwarte (autorskie i współautorskie) oraz inne formy wypowiedzi naukowych, jak choćby preprinty. Daje bowiem najwięcej możliwości wyszukiwawczych oraz ma duży potencjał, gdy idzie o sposoby prezentacji danych (warto jednak zastanowić się nad wykorzystaniem większej liczby odnośników - do oficjalnych stron czasopism, repozytoriów, bibliotek cyfrowych).

Co równie istotne, stanowi ona rzecz jasna zasadnicze źródło metainformacji dla nauk teologicznych, ale jej odbiorcami $-\mathrm{z}$ uwagi na różnorodny zakres tematyczny indeksowanych czasopism i prac zbiorowych - mogą być również przedstawiciele nauk humanistycznych i społecznych, a w szczególności filozofowie, historycy, socjologowie, religioznawcy, pedagodzy, kulturoznawcy, filolodzy, bibliolodzy $^{58}$, specjaliści komunikacji społecznej i nauk o rodzinie ${ }^{59}$.

Należy zatem mieć nadzieję, że nauki teologiczne zyskają w kolejnych latach bliskie kompletności narzędzie bibliograficzno-pełnotekstowe. Można to osiągnąć choćby poprzez konsolidację wielu rozproszonych dotąd źródeł bibliograficznych - w jedno, łatwe w obsłudze. Nagląca wydaje się potrzeba uporządkowania baz danych na stronach internetowych bibliotek - jeśli rekordy niegdyś tworzone do tych serwisów znalazły się w EBNT, to powinno się poinformować

${ }^{58}$ Por. np. B. Warząchowska, Z zagadnień bibliologicznych w Elektronicznej Bibliografii Nauk Teologicznych, w: Bibliografie specjalne. Rozwój i otwartość, red. B. Włodarczyk, J. Woźniak-Kasperek, Warszawa 2018, s. 189-204.

${ }^{59}$ Muc, Elektroniczna Bibliografia Nauk Teologicznych, s. 311. 
o tym użytkowników, a nawet rozważyć likwidację nieaktualizowanych baz. Innym torem będą się natomiast rozwijały bibliografie zespołów osobowych, podporządkowane nie tylko pełnionej przez nie funkcji informacyjnej i archiwizacyjnej, ale związanej z oceną parametryczną uczelni i zatrudnionych w nich badaczy.

\section{BIBLIOGRAFIA}

\section{Opracowania}

Babicz Marek, Stare druki Biblioteki Wyższego Seminarium Duchownego Towarzystwa Salezjańskiego w Lądzie nad Warta, „Archiwa, Biblioteki i Muzea Kościelne”, 80 (2003) s. 17-27.

Banach Ryszard, Biblioteka Wyższego Seminarium Duchownego w Tarnowie z perspektywy historycznej, „Fides. Biuletyn Bibliotek Kościelnych”, 21 (2015) nr 1 (40), s. 25-52.

Bednarczyk Jan, Biblioteka Papieskiej Akademii Teologicznej w Krakowie. Zarys działal$n o s ́ c i$, ,Analecta Cracoviensia. Studia philosophico-theologica edita a professoribus Cracoviae", 30/31 (1998/1999) s. 425-433.

Burnicka Katarzyna, Biblioteka Wydziału Teologicznego Uniwersytetu Mikołaja Kopernika $w$ Toruniu. Zarys problematyki, „Fides. Biuletyn Bibliotek Kościelnych”, 23 (2017) nr 2 (45), s. 57-70.

Ceynowa Tadeusz, Wstępny katalog starych druków Biblioteki Wyższego Seminarium Duchownego w Koszalinie, „Bibliotekarz Zachodniopomorski”, 55 (2014) nr 4, s. 5-19.

Dygdała Bogusław, Komputeryzacja Biblioteki Diecezjalnej w Toruniu: od MAK do NU$K A T$, „Fides. Biuletyn Bibliotek Kościelnych”, 22 (2016) nr 2 (43), s. 19-30.

Filipiuk Grzegorz, Archiwum i Biblioteka Warszawskiej Prowincji Kapucynów w Zakroczymiu, „Fides. Biuletyn Bibliotek Kościelnych”, (2007) nr 1-2 (24-25), s. 103-117.

Florianowicz Magdalena, Zbiór starych druków w Bibliotece Wyższego Seminarium Duchownego w Koszalinie, „Fides. Biuletyn Bibliotek Kościelnych”, 21 (2015) nr 1 (40), s. 81-102.

Florianowicz Magdalena, Zielonka Monika, Działalność i organizacja Biblioteki Wyższego Seminarium Duchownego w Koszalinie na przestrzeni trzydziestu lat istnienia, „Fides. Biuletyn Bibliotek Kościelnych”, (2012) nr 2 (35), s. 59-73.

Garwoliński Tomasz, Dzieje Biblioteki „Hosianum” (Braniewo - Olsztyn: 1565-2008), „Fides. Biuletyn Bibliotek Kościelnych”, (2008) nr 1-2 (26-27), s. 59-72.

Grabińska Urszula, Powstanie i rozwój Biblioteki Wydziału Teologicznego Uniwersytetu Opolskiego, „Fides. Biuletyn Bibliotek Kościelnych”, (2012) nr 2 (35), s. 39-57.

Grabuńczyk Tadeusz, Historia komputeryzacji Biblioteki Wydziału Teologicznego Uniwersytetu Opolskiego, „Fides. Biuletyn Bibliotek Kościelnych”, (2009) nr 1-2 (28-29), s. 12-26.

Grzybowski Michał Marian, Biblioteka Seminarium Duchownego od 1710 do 1990 roku, w: Biblioteka Wyższego Seminarium Duchownego w Płocku, red. W. Graczyk, Płock 2003, s. 73-136.

Ja.P. [Puchalski Jacek], Biblioteki kościelne, w: Encyklopedia książki, t. 1, Eseje - A-J, red. A. Żbikowska-Migoń i M. Skalska-Zlat, Wrocław 2017, s. 310-313.

Kęder Wojciech, Biblioteka opactwa cystersów w Mogile - Krakowie w XVII wieku, „Rocznik Bibliologiczno-Prasoznawczy”, 4/15 (2012) z. 1, s. 13-27. 
Klimecka Grażyna, Tynieckie rękopisy iluminiowane $w$ zbiorach Biblioteki Narodowej przykładem benedyktyńskiej kultury piśmienniczej $w$ XIV-XV w., w: Klasztor w kulturze średniowiecznej Polski. Materiaty z ogólnopolskiej konferencji naukowej zorganizowanej w Dąbrowie Niemodlińskiej w dniach 4-6 XI 1993 przez Instytut Historii WSP w Opolu i Instytut Historyczny Uniwersytetu Wrocławskiego, red. A. PobógLenartowicz, M. Derwich, Opole 1995, s. 289-297.

Krysiak Iwona, Biblioteka Instytutu Maryjno-Kolbiańskiego „,Kolbianum” w Niepokalanowie, „Fides. Biuletyn Bibliotek Kościelnych”, 21 (2015) nr 2 (41), s. 61-72.

Marszalska Jolanta M., Biblioteka opactwa benedyktynów w Tyńcu w świetle jej inwentarzy, „Roczniki Biblioteczne”, 41 (1997) z. 1/2, s. 29-42.

Muc Agata, Elektroniczna Bibliografia Nauk Teologicznych jako źródło do badań historyczno-teologicznych, „Archiwa, Biblioteki i Muzea Kościelne”, 109 (2018) s. 299314.

Nir Roman, Polskie bibliografie teologiczne, „Colloquium Salutis”, 4 (1972) s. 247-268.

Nowicka Agnieszka, Zarys dziejów Biblioteki Papieskiej Akademii Teologicznej w Krakowie, „Fides. Biuletyn Bibliotek Kościelnych”, (2005) nr 1-2 (20-21), s. 37-49.

Olszewski Mieczysław, Biblioteka Archidiecezjalnego Wyższego Seminarium Duchownego w Białymstoku, „Fides. Biuletyn Bibliotek Kościelnych”, (2005) nr 1/2 (20-21), s. 74-87.

Olszewski Mieczysław, Biblioteka AWSD w Biatymstoku, w: Archidiecezjalne Wyższe Seminarium Duchowne w Białymstoku 1945-1995. Ksiega jubileuszowa, red. S. Hołodok, Białystok 1995, s. 115-124.

Przybysz-Stawska Magdalena, Biblioteka Wyższego Seminarium Duchownego w Łodzi: wybrane zagadnienia, „Przegląd Biblioteczny”, 81 (2013) z. 4, s. 485-494.

Rulka Kazimierz, Inkunabuły w Bibliotece Seminarium Duchownego we Włocławku, „Fides. Biuletyn Bibliotek Kościelnych”, (1996) nr 1-2, s. 58-65.

Szulc Jolanta, Biblioteki Federacji Bibliotek Kościelnych FIDES: omówienie wyników ankiety przeprowadzonej w 2007 roku, „Fides. Biuletyn Bibliotek Kościelnych”, (2007) nr 1-2 (24-25), s. 5-23.

Ślemp Elżbieta, Biblioteka Wyższego Seminarium Duchownego w Przemyślu, „Fides. Biuletyn Bibliotek Kościelnych", (2005) nr 1-2 (20-21), s. 88-106.

Umiński Wacław, Zabytkowe oprawy w Bibliotece Zgromadzenia Księży Misjonarzy w Krakowie $w$ świetle wystaw, „Fides. Biuletyn Bibliotek Kościelnych”, 21 (2015) nr 2 (41), s. 3-18.

Walkusz Jan, Zbiory i biblioteki kościelne w Polsce. Wprowadzenie w problematykę, „Kościół w Polsce. Dzieje i Kultura", 4 (2005) s. 27-36.

Warząchowska Bogumiła, Federacja Bibliotek Kościelnych FIDES w przeddzień jubileuszu 25-lecia, „Bibliotheca Nostra. Śląski Kwartalnik Naukowy”, (2014) nr 2 (36), s. 73-89.

Warząchowska Bogumiła, Z zagadnień bibliologicznych w Elektronicznej Bibliografii Nauk Teologicznych, w: Bibliografie specjalne. Rozwój i otwartość, red. B. Włodarczyk, J. Woźniak-Kasperek, Warszawa 2018, s. 189-204.

Witczak Jerzy, Federacja Bibliotek Kościelnych FIDES po dwudziestu latach, „Bibliotekarz", (2013) nr 7-8, s. 12-17.

Witczak Jerzy, Funkcjonowanie centralnego serwisu informacji katalogowej i bibliograficznej FIDES w 2011 roku, „Fides. Biuletyn Bibliotek Kościelnych”, (2012) nr 1 (34), s. $175-179$.

Witkowska Jadwiga, Jubileusz trzydziestolecia Biblioteki Parafialnej w Trzciance, „Fides. Biuletyn Bibliotek Kościelnych”, (2014) nr 1 (38), s. 243-245. 
Zezula Barbara, Biblioteka Uniwersytecka Katolickiego Uniwersytetu Lubelskiego Jana Pawła II wczoraj i dziś, „Fides. Biuletyn Bibliotek Kościelnych”, 22 (2016) nr 1 (42), s. 3-20.

\section{Netografia}

Aktualizacja danych, http://biblio.fides.org.pl/ (dostęp: 02.03.2020).

Archiwum i Biblioteka OO. Karmelitów Bosych na Piasku, https://www.facebook.com/ Karmelici.na.Piasku/ (dostęp: 20.09.2019).

Baza: FIDES - ADRESY BIBLIOTEK, http://www.fides.org.pl/cgi-bin/makwww/ makwww.exe?BM=03\&IZ=Typ\%F3w-inst. (dostęp: 20.09.2019).

Chlewicka Aldona, Biblioteka Wyższego Seminarium Duchownego Zgromadzenia Ducha Świętego w Bydgoszczy, s. 103-119, https://repozytorium.ukw.edu.pl/bitstream/ handle/item/5677/Biblioteka\%20Wy\%c5\%bcszego\%20Seminarium\%20Duchownego\%20Zgromadzenia $\% 20$ Ducha $\% 20 \%$ c5\%9awi\%c4\%99tego $\% 20$ w $\% 20$ Bydgoszczy.pdf? sequence=1\&isAllowed=y (dostęp: 04.11.2019).

Elektroniczna Bibliografia Nauk Teologicznych, https://www.fides.org.pl/index.php/bazy-on-line/bazy-centralne/59-elektroniczna-bibliografia-nauk-teologicznych (dostęp: 14.11.2019).

Graczyk Waldemar, Biblioteka płockiego Seminarium - przeszłość i teraźniejszość, „Niedziela", edycja płocka, 2003, nr 50, https:/www.niedziela.pl/artykul/22785/nd/Biblioteka-plockiego-Seminarium (dostęp: 04.11.2019).

Polska Bibliografia Nauk Kościelnych 1940-1979, http://bazy.biblioteka.uksw.edu.pl/bnk. php (dostęp: 14.11.2019).

Polska Bibliografia Tomistyczna, https://www.it.dominikanie.pl/projekty-it/polska-bibliogr-tomist/ (dostęp: 14.11.2019).

Seweryn Anna, Contemporary forms of communication with library users - the experiences of theological libraries in Poland, https:/theo.kuleuven.be/apps/press/beth/ files/2019/09/BETH_Seweryn_mini.pdf (dostęp: 18.11.2019).

Sułecki Szymon, Księgozbiór klasżtoru karmelitów na Piasku w Krakowie, Kraków 2014, https://www.academia.edu/8990832/Ksi\%C4\%99gozbi\%C3\%B3r_klasztoru_karmelit\%C3\%B3w_na_Piasku_w_Krakowie (dostęp: 20.09.2019). 


\title{
THEOLOGICAL HERITAGE IN THE ELECTRONIC BIBLIOGRAPHIC DATABASES OF THE FEDERATION OF THE CHURCH LIBRARIES FIDES. REVIEW OF INITIATIVES
}

\begin{abstract}
Summary
The websites of 80 libraries belonging to the Federation of the Church Libraries 'Fides' have been analysed in search of information about their bibliographic projects. The examples present the experience of the institutions in the development of information tools and the protection of the theological heritage acquired over the years. Selected bibliographical databases were characterized, divided into subject bibliographies and bibliographies of issues, bibliographies of serial publications and journal contents, and personal and collective bibliographies. It was established that the most important bibliographic product of the libraries associated under 'Fides' is the Electronic Bibliography of Theological Sciences, co-created with the National Library of Poland in Warsaw. The libraries under study, on the other hand, most often developed bibliographies of journal contents, which were partly absorbed by the subject bibliography, and less frequently by other subject bibliographies and bibliographies of journal contents issues and collective bibliographies.
\end{abstract}

Keywords: bibliographic database; bibliography; church library; theological heritage; Federation of the Church Libraries 'Fides' 